\title{
Influence of Vehicles and Penetration Enhancers on the Permeation of Cinnarizine Through the Skin
}

\section{Taşıyıcıların ve Penetrasyon Artırıcıların Sinarizinin Deriden Permeasyonuna Etkisi}

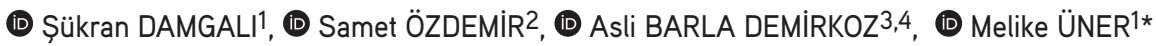 \\ 1/stanbul University, Faculty of Pharmacy, Department of Pharmaceutical Technology, Istanbul, Turkey \\ 2Istanbul Health and Technology University, Faculty of Pharmacy, Department of Pharmaceutical Technology, Istanbul, Turkey \\ ${ }^{3}$ Aromsa Flavours and Food Additives Inc. Co., Department of Research and Development Center, Kocaeli, Turkey \\ 4 Halic University, Faculty of Health Sciences, Department of Nutrition and Dietetics, Istanbul, Turkey
}

\begin{abstract}
Objectives: The aim of this study was to determine the influence of vehicles and penetration enhancers on the penetration and permeation of cinnarizine (CNZ) through the skin.

Materials and Methods: Topical formulations based on hydrogel, o/w emulsion and oleaginous cream were prepared. After determination of physical properties of formulations, the penetration and permeation of CNZ through the stratum corneum and full-thickness skin was investigated by an ex vivo study.

Results: The cumulative amount of CNZ permeated from the base hydrogel formulation was about 5 times higher than the base o/w emulsion and base oleaginous cream formulations. The incorporation of penetration enhancers to the base hydrogel and o/w emulsion formulations generally increased CNZ penetration through the skin. Transcutol ${ }^{\circledR}$ was confirmed to provide the highest penetration in the hydrogel formulation. Propylene glycol was found to be the most suitable penetration enhancer for CNZ in the oleaginous cream. Glycerol and oleic acid displayed the highest effect in the o/w emulsion.

Conclusion: It was concluded that the hydrogel containing Transcuto ${ }^{\circledR}$ provided the highest penetration through the skin among all formulations and this formulation could be an alternative to the oral route in the treatment of Ménière's disease and motion sickness. Thus, the risk of systemic side effects caused by oral medication can be reduced or eliminated.
\end{abstract}

Key words: Cinnarizine, Ménière's disease, motion sickness, penetration enhancers, skin permeation

öz

Amaç: Bu çalıșmanın amacı taşıyıcıların ve penetrasyon artırıııların sinarizinin (CNZ) deriden penetrasyonu ve permeasyonu üzerindeki etkisini tayin etmektir.

Gereç ve Yöntemler: Hidrojel, y/s emülsiyonu ve yağlı krem bazlı topikal formülasyonlar hazırlandı. Formülasyonların fiziksel özelliklerinin tayininden sonra, CNZ'nin stratum corneum ve tam kalınlıkta deriye penetrasyon ve permeasyonu bir ex vivo çalışma ile incelendi.

Bulgular: Baz hidrojel formülasyonundan nüfuz eden kümülatif CNZ'nin miktarı, baz y/s emülsiyonu ve baz yağlı krem formülasyonlarından yaklaşık 5 kat daha yüksekti. Baz hidrojel ve y/s emülsiyon formülasyonlarına penetrasyon artırıcıların ilavesi, genellikle CNZ'nin deriden penetrasyonunu artırdı. Transcutol ${ }^{\circledR \prime}$ un hidrojel formülasyonunda en yüksek pentrasyonu sağladığı doğrulandı. CNZ için yağlı kremde en uygun penetrasyon artırıCı propilen glikol olarak bulundu. Gliserol ve oleik asit y/s emülsiyonunda en yüksek etkiyi gösterdi.

Sonuç: Transcutol ${ }^{\circledR}$ içeren hidrojelin tüm formülasyonlar arasında deriden en yüksek CNZ geçişi sağladığı ve bu formülasyonun Meniere hastalığı ile hareket hastalığının tedavisinde oral yola bir alternatif olabileceği sonucuna varıldı. Böylece ağızdan alınan ilacın neden olduğu sistemik yan etki riski azaltılabilir veya ortadan kaldırılabilir.

Anahtar kelimeler: Sinarizin, Meniere hastalığı, hareket hastalığı, penetrasyon artırıcılar, deri geçirgenliği 


\section{INTRODUCTION}

Cinnarizine (CNZ) is a piperazine derivative histamine $\mathrm{H} 1$ antagonist and a selective calcium channel blocker drug., ${ }^{12}$ It is commonly prescribed for peripheral and cerebral disorders, vertigo, tinnitus, nystagmus, motion sickness and Ménière's disease. There are only oral formulations in the pharmaceutical market of CNZ. The oral bioavailability of CNZ is low and variable. Many side effects of CNZ have been reported. Side effects of CNZ range from mild to quite severe. Its more common side effects are drowsiness and blurred vision, sweating, dry mouth, headache, skin problems, lethargy, gastrointestinal irritation, hypersensitivity reactions, muscle rigidity and tremor. CNZ can easily pass blood-brain barrier and it displays a sedative activity. Thus, its use by pilots and aircrew who must be dependably alert due to increased levels of drowsiness caused by the medication, is generally limited. Long-term CNZ therapy may cause weight gain, depressive conditions and several extrapyramidal syndromes, including tremor, acute and chronic Parkinsonism. CNZ can cause a tardive dyskinesia similarly to neuroleptic agents.

An alternative route to oral administration can provide an effective drug therapy. The transdermal route can be stated as one of the most reliable routes of application. Transdermal dosage forms are an alternative for the delivery of actives that have low oral bioavailability and systemic side effects. Moreover, transdermal delivery allows for the avoidance of the first-pass metabolism. There are various strategies to accelerate the drug passing through the skin. Thus, immediate and moderate action can also be observed. Penetration enhancers are required to enhance permeation through the skin by different penetration mechanisms for optimization of well-formulating topical products. Thus, to obtain an efficient treatment can be provided via the transdermal route. Penetration enhancers essentially improve transdermal delivery of both lipophilic and hydrophilic actives by decreasing barrier resistance of the skin.,4 Polyols, fatty acids and terpenes are commonly used as penetration enhancers. Diethyleneglycol monoethylether [Transcutol ${ }^{\circledR}(\mathrm{Tc})$ ], propylene glycol (PG), glycerol (Gl), oleic acid (OA) and limonene $(\mathrm{L})$ are some of the most generally used penetration enhancers. They can carry drug delivery further through the skin displaying different mechanisms, through upper layers of the skin, mainly the stratum corneum. Tc and PG alter thermodynamic activity of permeants in their vehicles after permeating through tissues themselves at first. Afterwards, permeants diffuse into the skin by modification of driving forces for diffusion..$^{5-7}$ The activity of $P G$ is also pronounced to result from solvatation of $\alpha$-keratin within the stratum corneum, herewith promoting permeation by reducing drug-tissue binding. $L$ promotes the permeation of lipophilic and amphiphilic penetrants by increasing their diffusion in the stratum corneum. ${ }^{8,9} \mathrm{OA}$, a long-chain fatty acid, enhances percutaneous drug absorption by decreasing the phase transition temperatures of the skin lipids. A polar head group attached to the alkyl chain of OA conducts its potential enhancement function. However, Gl displays its penetration enhancing effect when along with water. ${ }^{10}$
In this study, it was prepared topical formulations of CNZ to overcome side effects caused by oral administration of the drug and to provide an alternative therapy in Ménière's disease and motion sickness. For this purpose, effects of various traditional vehicles and penetration enhancers on the permeation of CNZ were investigated. Topical formulations based on a hydrogel (G), o/w emulsion (E) and oleaginous cream (OC) were prepared and their physical characteristics were determined. Penetration and permeation of CNZ through the stratum corneum and skin were investigated with an ex vivo study. This study was conducted on the abdominal skin of Wistar Albino rats since the rat skin can be used as a model for investigation of transdermal drug delivery through the human skin as reported in earlier studies. In vivo and ex vivo tests on rats have been demonstrated that can be used for searching properties required from actives and/or vehicles for skin delivery. ${ }^{11-14}$

\section{MATERIALS AND METHODS}

CNZ was kindly provided from Nobel llaç San. ve Tic. A.Ș., Turkey. Hydroxypropyl methylcellulose (Methoce ${ }^{\mathrm{TM}} \mathrm{K} 15 \mathrm{M}$ ) (HPMC) was kindly provided by Colorcon (Turkey). PG, OA, polyethylene glycol (PEG 400), Gl and Tween ${ }^{\circledR} 80$ were purchased from Merck (Germany). Polyvinylpyrrolidone ${ }^{\circledR}$ K90 (PVP K90), cetyl alcohol and liquid paraffine were purchased from Sigma-Aldrich (Germany). Stearic acid and glyceryl monostearate were purchased from Doğa İlaç Hammaddeleri Tic. Ltd. Şti. (Turkey). Tc was provided by Gattéfosse (France). All other reagents and chemicals were of analytical grade.

\section{Preparation of topical formulations}

The composition of base CNZ formulations ( $G, E$, and $O C$ ) is presented in Table 1. Penetration enhancers ( $T c, P G, G$ and $O A$ ) were added to these formulations (Table 2). $L$ was also added to base formulations at the rate of $5 \%$. However, they went to the phase separation or they lost their homogeneity within one week. Thus, they were excluded from the study. As an addition, Tc was confirmed to be incompatible with the base formulation OC.

\section{Quantification of CNZ}

The high performance liquid chromatography (HPLC) method was verified for analytical quantification of the drug in samples obtained during experiments. International Council for Harmonisation (ICH) guideline for the method validation procedure was considered for this purpose. ${ }^{15}$ Linearity, intra-day and inter-day precision, accuracy, recovery and specifity were determined for verification of the method. Each verification analysis was replicated 6 times.

For this purpose, a HPLC apparatus (Shimadzu LC-20AT) was equipped with an ultraiole/visible detector (Shimadzu SPD20A) and autosampler (Shimadzu SIL-20A HT). The separation was carried out using a TC-C $_{18}$ column $(5 \mu \mathrm{m}, 4.6 \times 250 \mathrm{~mm})$ (Agilent Tech, Germany) at $40{ }^{\circ} \mathrm{C}$. Samples were detected under $1 \mathrm{~mL} / \mathrm{min}$ flow rate of acetonitrile: ammonium phosphate monobasic solution $(\mathrm{pH}: 4.5)(6: 4, \mathrm{v} / \mathrm{v})$ as the mobile phase at $253 \mathrm{~nm} .0 .24 \mathrm{mg} / \mathrm{mL}$ stock standard solution of CNZ in methanol was prepared to evaluate the linearity of the method under the 
Table 1. Constituents of the base formulations

\begin{tabular}{llll} 
Constituents $(\%, w / w)$ & G & E & OC \\
\hline CNZ & 2.5 & 2.5 & 2.5 \\
\hline HPMC & 3.15 & - & - \\
\hline PVP K90 & 0.35 & - & - \\
\hline PEG 400 & 15 & - & - \\
\hline Vaseline & - & 8 & 75 \\
\hline Liquid paraffine & - & 19 & 12.5 \\
\hline Stearic acid & - & 2 & 10 \\
\hline Cetyl alcohol & - & 2 & - \\
\hline Tween ${ }^{\circledR} 80$ & - & 4 & - \\
\hline GMS & - & 1 & - \\
\hline Saline & 22.5 & - & - \\
\hline Distilled water & 56.5 & 61.5 & - \\
\hline Methylparaben & 0.15 & 0.15 & - \\
\hline Propylparaben & - & 0.15 & 0.15 \\
\hline
\end{tabular}

G: Hydrogel, E: o/w emulsion, OC: Oleaginous cream, CNZ: Cinnarizine, HPMC: Hydroxypropyl methylcellulose, PVP: Polyvinylpyrrolidone, PEG: Polyethylene glycol, GMS: Glyceryl monostearate

Table 2. Formulations containing penetration enhancers

\begin{tabular}{lcccc} 
Formulations & \multicolumn{5}{c}{ Enhancers (\%) } \\
\hline G* $^{*}$ & Tc & PG & Gl & OA \\
\hline G-TC & - & - & - & - \\
\hline G-PG & 5 & - & - & - \\
\hline G-Gl & - & 5 & - & - \\
\hline G-OA & - & - & 5 & - \\
\hline E* $^{*}$ & - & - & - & 2 \\
\hline E-TC & - & - & - & - \\
\hline E-PG & 5 & - & - & - \\
\hline E-Gl & - & 5 & - & - \\
\hline E-OA & - & - & 5 & - \\
\hline OC* & - & - & - & 5 \\
\hline OC-PG & - & - & - & - \\
\hline OC-Gl & - & 5 & - & - \\
\hline OC-OA & - & - & 5 & - \\
\hline
\end{tabular}

${ }^{*} G, E$, and $O C$ are base formulations. G: Hydrogel, $E:$ o/w emulsion, $O C$ : Oleaginous cream, Tc: Transcutol ${ }^{\circledR}$, PG: Propylene glycol, Gl: Glycerole, OA: Oleic acid, G: Hydrogel

selected conditions. Drug determination was carried out at six concentrations $(4-24 \mu \mathrm{g} / \mathrm{mL})$ for providing the calibration curve.

\section{Solubility of $C N Z$ in various mediums}

The solubility of CNZ was determined in various media according to the method reported in USP XIX.16 $15 \mathrm{~mL}$ of the dissolution medium was placed in four $25-\mathrm{mL}$ flasks for this purpose. A quantity of CNZ was added to each flask that was greater than the quantity expected to dissolve in the medium. Flasks were closed and they were fixed in a constant temperature water bath (Daihan Scientific, Korea) adjusted to $25 \pm 1^{\circ} \mathrm{C}$. The apparatus was maintained under $200 \mathrm{rpm}$ continuous agitation. Dispersions were filtered through $S \& S^{5893}$ blue ribbon papers (2 $\mu \mathrm{m}$ pore size, Schleicher \& Schuell, Germany) after $24 \mathrm{~h}$ agitation. Measured portions of clear supernatants were removed and the solubility of CNZ was determined with HPLC.

\section{Partition coefficient}

The partition coefficient of CNZ between isopropyl myristate and distilled water was determined using the shake flask method, following the guidelines of the European Chemical Bureau (European-Chemical-Bureau, Dir 92/69/EEC).

\section{In vitro drug release of formulations}

$0.45 \mu \mathrm{m}$ cellulose acetate membranes (Sartorius, Germany) were kept in the receptor phase, a physiological saline solution (PSS): PEG 400 mixture (6:4, v/v) over night. Membranes were placed between two halves of Franz-type diffusion cells with $3.15 \mathrm{~cm}^{2}$ surface area and $33.2 \mathrm{~mL}$ volume containing the receptor phase. $1 \mathrm{~g}$ topical formulation was placed on to the membrane in the donor phase. The receptor phase was maintained at $37 \pm 0.5^{\circ} \mathrm{C}$ constant temperature during this study for $6 \mathrm{~h}$. Samples were taken from the receptor phase at certain time intervals. Cumulative amounts of CNZ released $\left(\mathrm{mg} / \mathrm{cm}^{2}\right)$ determined by HPLC after samples were filtered through $\mathrm{S}$ \& $\mathrm{S}^{5893}$ blue ribbon papers. Six replicates were conducted for each formulation. Drug release profiles were obtained by plotting cumulative amounts of the drug as the function of time and release profiles were evaluated using different kinetic models (zero order, first order and Higuchi square-root model).17,18 The exponent value $(n)$ of the Korsmeyer-Peppas kinetic model was considered for specifying drug release mechanism well un-known or for more than one type of release mechanisms comprised.

\section{Ex vivo skin penetration and permeation studies}

2.5-3 months aged male Wistar Albino rats (200-250 g) were provided from Aziz Sancar Institute of Experimental Medicine. The experimental protocol the Local Ethical Committee approved the experimental protocol of Animal Experiments (17.12.2013, no: 2013/131). Animals were housed in plastic cages at $22 \pm 1^{\circ} \mathrm{C}$ and $60 \pm 1 \%$ humidity under $12 \mathrm{~h}$ light-dark cycle. They were given standard laboratory diet and tap water ad libitum. Precisely shaved full-thickness abdominal rat skins were taken after they were sacrificed for ex vivo skin penetration and permeation assessments. The underlying fatty tissue was removed with blunt dissection without damaging the epidermal surface. Skins were placed between two halves of Franztype diffusion cells. $1 \mathrm{~g}$ formulation was applied on the skin in the donor chamber of cells. PSS: PEG $400(6: 4, v / v)$, was 
used as the receptor phase. This study was continued for 6 $\mathrm{h}$ at $37 \pm 1^{\circ} \mathrm{C}$ constant temperature. The cumulative amount of CNZ permeated was verified in samples collected from the receptor phase at predetermined time intervals by HPLC. Three replicates were conducted for each formulation. The cumulative amount $\left(Q_{n}, \mathrm{mcg} / \mathrm{cm}^{2}\right)$ of $C N Z$ permeated through the skin was calculated and cumulative drug amounts were plotted as the function of time $(t, h) \cdot{ }^{19-21}$ The steady state flux of the drug $\left(J_{s^{\prime}}\right.$ $\mathrm{mcg} / \mathrm{cm}^{2} / \mathrm{h}$ ) was ascertained from the slope of linear part of plot using the linear regression analysis $(r>0.99)$ and then the efficiency of the penetration enhancers were determined.

The penetration of CNZ was assayed through the skin. A tape stripping study was conducted. For this purpose, abdominal rat skins over receptor chambers of Franz-type diffusion cells were used. Excess formulation in contact with the stratum corneum was carefully expunged using cotton swabs. ${ }^{22}$ Circular PVC tape strip sticking plaster pieces in $1 \mathrm{~cm}$ semidiameter (Ve-ge ${ }^{\circledR}$, İzmir, Turkey) was applied with a light pressure over the diffusion area. Then, it was removed with forceps. The first two strips were thrown away, because they collected residue of the formulation within crevices of the skin surface. The next 10 sticking plaster pieces were then applied using uniform firm pressure to obtain the formulation residue deposited within the skin tissue. They were then removed with uniform force rapidly using forceps. All tape strip sticking plaster pieces were collected in a $25 \mathrm{~mL}$ flask for extracting the drug content. For extracting CNZ, $10 \mathrm{~mL}$ ethanol was added to flasks and all flasks were tightly closed. They were fixed in a water bath at $25 \pm 1^{\circ} \mathrm{C}$. The apparatus was adjusted to $160 \mathrm{rpm}$ continuous agitation for $24 \mathrm{~h}$. Flasks' contents were then filtered through S \& S 5893 blue ribbon papers. Measured portions of clear supernatants were removed from each flask for determination of CNZ content by HPLC. Subsequently, the solubility constraint $\left(\sigma_{s c}\right)$ of CNZ in the stratum corneum was also calculated [log $\sigma_{\text {sc }}: 1.911$ $\left(10^{3} /\right.$ melting point as Kelvin) - 2.956]. ${ }^{23}$ The melting point of CNZ was obtained by differential scanning calorimetry (DSC) analysis. For this purpose, a DSC apparatus (Universal V4.5A TA Instruments, U.S.A.) was employed. 9.7-mg sample was weighted into aluminum pans of the apparatus and heated with $10^{\circ} \mathrm{C} / \mathrm{min}$ heating rate under $50 \mathrm{~mL} / \mathrm{min} \mathrm{N}_{2}$ flow. Thermogram of the sample was obtained indicating its melting point and enthalpy.

\section{Statistical analyses}

Drug release and permeation profiles of the formulations obtained from in vitro and ex vivo experiments and data obtained from the tape stripping experiment were compared using OneWay ANOVA test and subsequent Tukey post hoc pairwise tests. The Minitab ${ }^{\circledR} 18$ Statistical Software was used for this purpose by setting the significance level as $\alpha$ : 0.05 .

\section{RESULTS AND DISCUSSION}

\section{Analytical quantification}

The analytical quantification of CNZ by HPLC was verified according to the instructions of the $\mathrm{ICH}$ Tripartite Guideline. ${ }^{15}$ The representative linear equation was $A=a C+b$, where $A$ is the absorbance, $\mathrm{a}$ is the slope, $\mathrm{C}$ is the concentration and $\mathrm{b}$ is the intercept. The regression equation was $A=81417.9 \mathrm{C}+3405.3$ (correlation coefficient, $r=0.9999)$. The retention time of $\mathrm{CNZ}$ was found as $5.8 \mathrm{~min}$ (Figure $1 \mathrm{~A}$ ). Limits of detection and quantification of the quantification method were determined as $5.929 \mathrm{ng} / \mathrm{mL}$ and $17.968 \mathrm{ng} / \mathrm{mL}$, respectively. Relative standard deviations for accuracy, intra-day and inter-day precision of the methods were below $2 \%$. The recovery of CNZ was found to be $99.87 \pm 0.06-100.74 \pm 0.03 \%$. Chromatograms of the receptor phase and placebo base formulations demonstrated the specifity of the method (Figure 1B-E). Chromatograms of the formulations containing penetration enhancers (TC, PG, GL and

$\mathbf{A}$

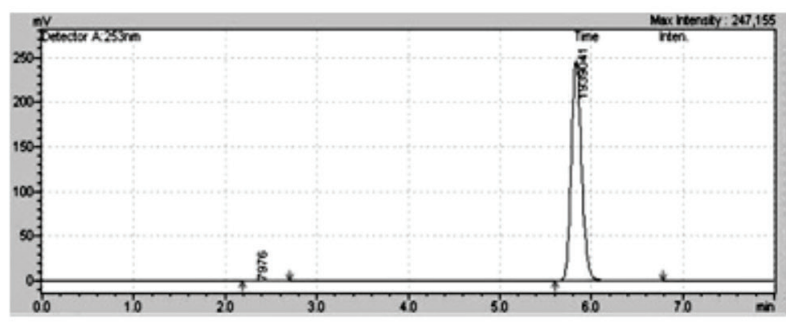

B

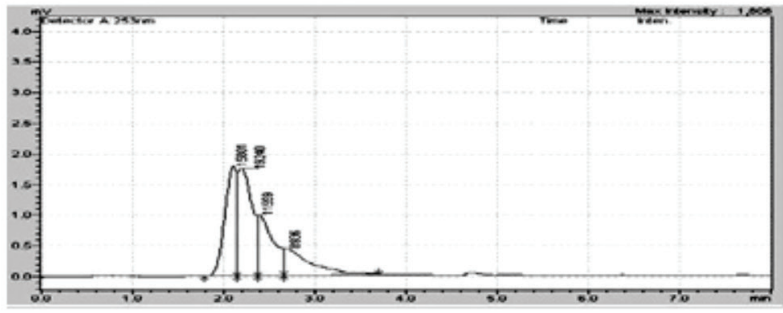

C

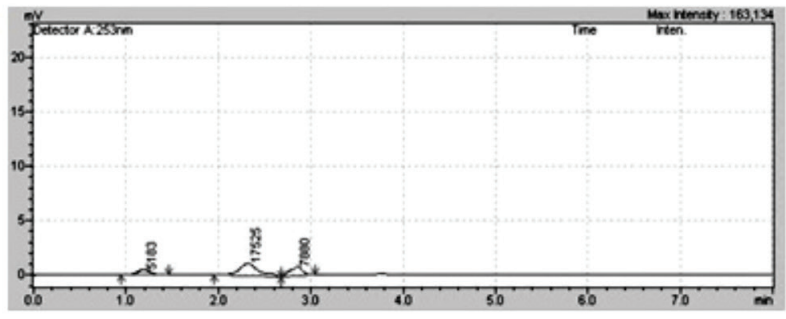

D

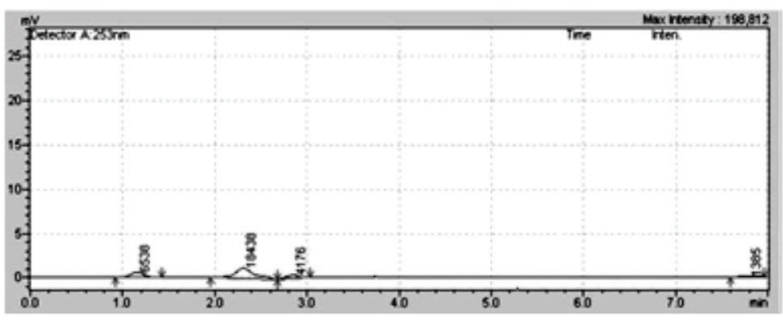

$\mathbf{E}$

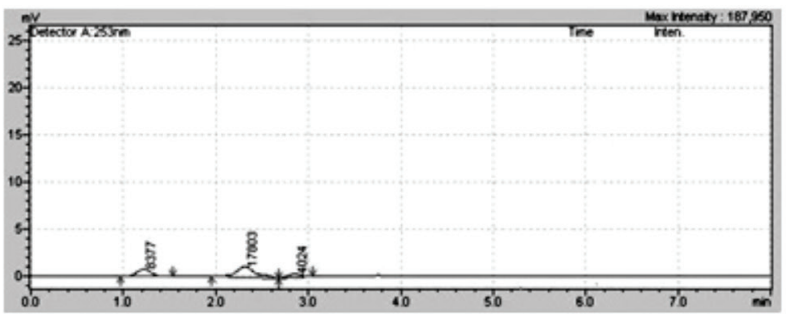

Figure 1. HPLC chromatograms - (A) CNZ, (B) receptor phase and placebo base formulations [(C) G, (D) E and (E) OC]

HPLC: High performance liquid chromatography, CNZ: Cinnarizine, G: Hydrogel, E: o/w emulsion, OC: Oleaginous cream 
$\mathrm{OA}$, individually at the $5 \%$ rate in the formulations) were also verified the specificity of the method (they are not presented). Peaks of ingredients in the formulations were observed not to interfere with the drug peak.

\section{Solubility of CNZ}

The solubility of $\mathrm{CNZ}$ in various media at $25^{\circ} \mathrm{C}$ are represented in Table 3. PSS:PEG 400 mixture $(6: 4, \mathrm{v} / \mathrm{v})$ was decided to be used as the receptor phase since the solubility of CNZ was found to be the highest in it.

In vitro drug release of formulations

Table 3. Solubility of CNZ in different media at $25 \pm 1^{\circ} \mathrm{C}$

\begin{tabular}{lll} 
Mediums & \multicolumn{2}{l}{ Solubility $(\mathrm{mg} / \mathrm{mL})$} \\
\hline pH 7.4 PBS & $0.017 \pm 0.004$ & p.i. \\
\hline pH 6.8 PBS & $0.027 \pm 0.008$ & p.i. \\
\hline $5 \%$ bovine serum albumin in PSS $(\mathrm{w} / \mathrm{v})$ & $0.024 \pm 0.006$ & p.i. \\
\hline PSS: PEG $400(8: 2)$ & $0.601 \pm 0.013$ & vss \\
\hline Water & $0.749 \pm 0.005$ & vss \\
\hline PSS: PEG 400 (6:4) & $1.406 \pm 0.010$ & s.s. \\
\hline
\end{tabular}

According to the European and the United States Pharmacopeias, pi: Practically in soluble, vss: Very slightly soluble, ss: Slightly soluble, PBS: Phosphate buffered saline, PSS: Physiological saline solution, PEG: Polyethylene glycol, CNZ: Cinnarizine

To achieve the sink condition, the receptor phase must have a high capacity to dissolve or carry away the drug. An acceptable sink condition has been reported to be one where the maximum concentration of the drug in the receptor phase reached during the experiment does not exceed $30 \%$ of its maximum solubility in the receptor phase. ${ }^{24} \mathrm{It}$ is provided in a volume of the medium that is at least 3-10 times the saturation volume. The solubility of CNZ at $37 \pm 1^{\circ} \mathrm{C}$ was also determined and it was found to be $2.352 \pm 0.012 \mathrm{mg} / \mathrm{mL}$. Thus, the volume of the receptor phase allowed to maintain the sink condition.

Permeation characteristics of a drug through the skin can't be judged with in vitro drug release experiments. But it avail researchers to reckon some reasons for low drug penetration rate, including the affinity of the drug to the vehicle. ${ }^{25,26} \mathrm{CNZ}$ was confirmed to display the highest affinity to OC compared to $\mathrm{G}$ and $\mathrm{E}$ ( $p<0.05$ ). The emulsion formulation $\mathrm{E}$ was confirmed to display the highest drug release rate among base formulations up to $6^{\text {th }}$ hours ( $p<0.05$ ) (Figure 2, Table 4). G $\left(0.293 \mathrm{mg} / \mathrm{cm}^{2} / \mathrm{h}\right.$ ) and $\mathrm{OC}\left(0.151 \mathrm{mg} / \mathrm{cm}^{2} / \mathrm{h}\right)$ respectively, followed E $(0.326 \mathrm{mg} /$ $\mathrm{cm}^{2} / \mathrm{h}$ ). It was determined that the incorporation of penetration enhancers to the base formulations led to a significant increase in drug release rate of the vehicles in the case of formulations $E$ and $G(p<0.05)$ while an opposite situation was occurring for $O C$ with all penetration enhancers. Tc and $\mathrm{Gl}$ addition to formulation $E$ and $P G$ addition to formulation $G$ provided the highest release rate of drug from vehicles ( $p>0.05)$. Due to the lipophilic character of CNZ resulted in its retention in the base $O C$ formulation. ${ }^{27}$ Moreover, the incorporation of penetration enhancers ( $P G, G$ and $O A$ ) to $O C$ statistically insignificantly
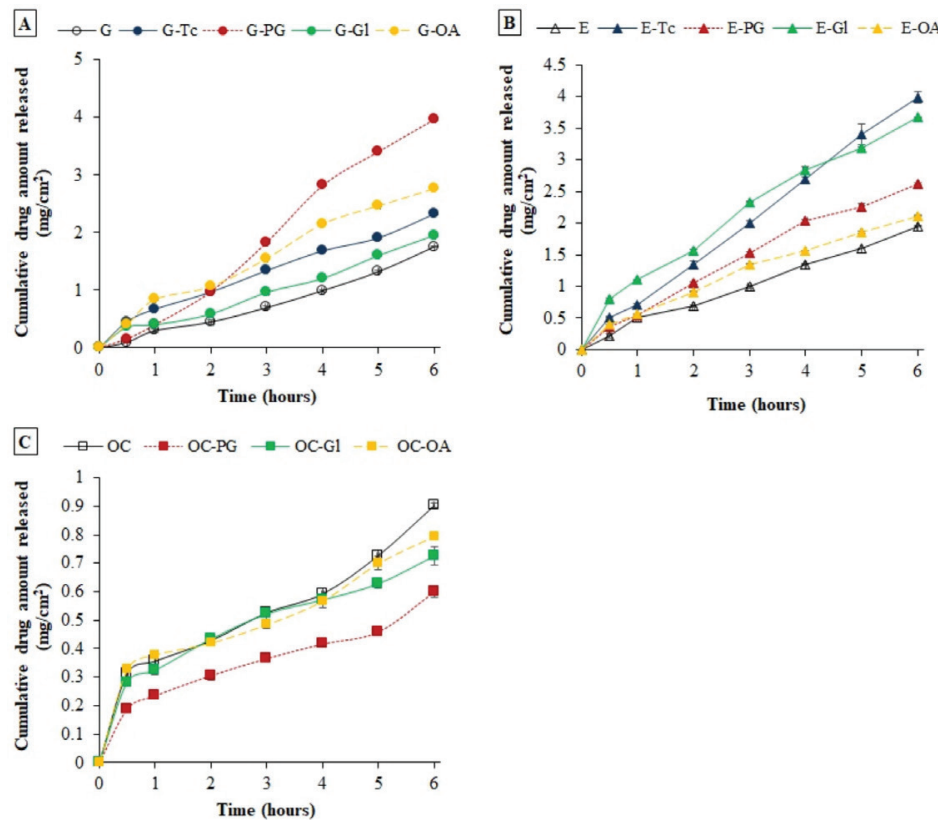

Figure 2. CNZ release profiles of topical formulations in PSS:PEG 400 (6:4, $\mathrm{v} / \mathrm{v}$ ). (A) hydrogel based formulations, (B) o/w emulsion based formulations and $(C)$ oleaginous cream based formulations

CNZ: Cinnarizine, PSS: Physiological saline solution, PEG: Polyethylene glycol, G: Hydrogel, E: o/w emulsion, OC: Oleaginous cream, Tc: Transcutol®, PG: Propylene glycol, Gl: Glycerole, OA: Oleic acid

changed the drug release rate and slower drug release profiles were obtained from formulations OC-OA, OC-GI, and OC-PG ( $p>0.05$ ) compared to the emulsion and hydrogel formulations. Thus, it was affirmed that increase in the solubility of the drug in the vehicle resulted in slower drug release. ${ }^{25}$ Emulsion and hydrogel based formulations displayed anomalous transport of drug release because of kinetic modeling (Table 4). This phenomena can be attributed to two mechanisms conducted drug release, diffusion and polymer relaxation in hydrogel formulations or drug release free from concentration in emulsion formulations.

\section{Ex vivo skin permeation and penetration studies}

CNZ permeation from topical formulations through rat skin was ascertained to involve in the polarity of the formulations and type of penetration enhancers as reported earlier studies conducted on skin permeation of lipophilic drugs. ${ }^{27}$ Polar hydrogel structure provided the highest drug permeation rates among other vehicles (Figure 3, Table 5). This phenomena can be attributed to the high partition coefficient of CNZ (log P: $5.74 \pm 0.03$ in isopropyl myristate/water). G significantly displayed the highest permeation rate followed by $\mathrm{E}$ and $\mathrm{OC}$ ( $p<0.05)$, respectively. Tc was found as the most effective penetration enhancer compared to $\mathrm{PG}, \mathrm{GL}$ and $\mathrm{OA}$ for hydrogel based formulations ( $p<0.05)$. The highest drug permeation rate was obtained in formulation G-Tc $\left(0.110 \pm 0 \mathrm{mg} / \mathrm{cm}^{2} / \mathrm{h}\right)$ followed by G-Gl $\left(0.062 \pm 0.002 \mathrm{mg} / \mathrm{cm}^{2} / \mathrm{h}\right), \mathrm{G}-P G\left(0.057 \pm 0.001 \mathrm{mg} / \mathrm{cm}^{2} / \mathrm{h}\right)$ and $\mathrm{G}-\mathrm{OA}\left(0.050 \pm 0.001 \mathrm{mg} / \mathrm{cm}^{2} / \mathrm{h}\right)$. Although emulsion based formulations followed $G$ formulations in the same penetration enhancer order, differences between emulsion and oleaginous cream based formulations were insignificant ( $p>0.05)$. Tc 
Table 4. Release parameters of CNZ from the formulations for $6 \mathrm{~h}$ and kinetic modeling of release profiles

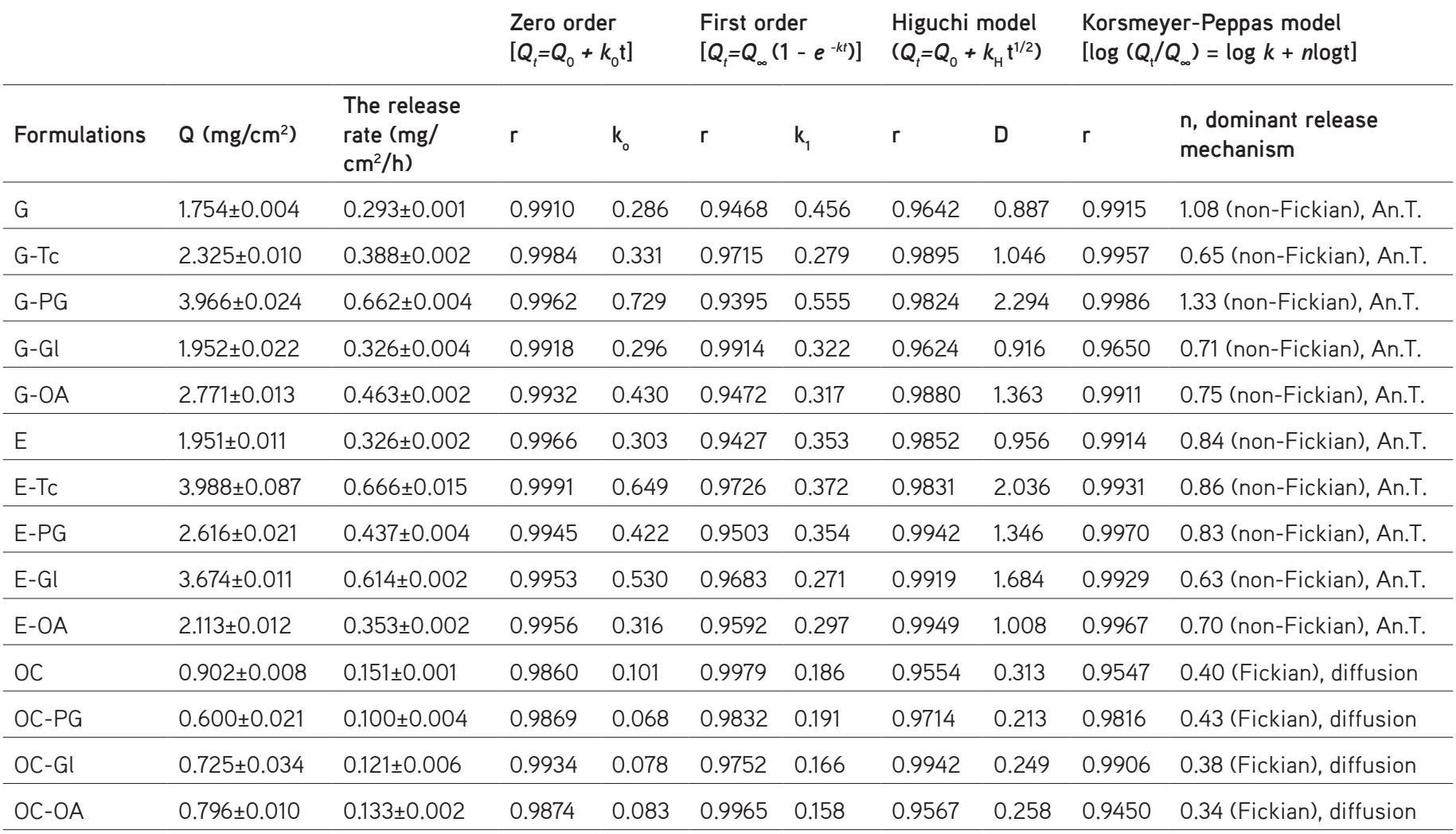

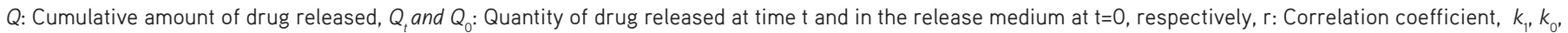

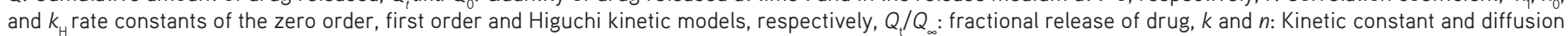

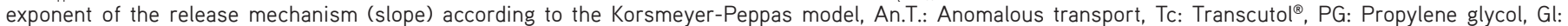
Glycerole, OA: Oleic acid, OC: Oleaginous cream, CNZ: Cinnarizine, G: Hydrogel, E: o/w emulsion

and PG possibly contributed to their own permeation through tissues and modified the thermodynamic activity of CNZ before modification of driving forces for drug diffusion as reported earlier. ${ }^{19,28}$ Solvatation of $a$-keratin within the stratum corneum by $P G$ was additionally be claimed to improve the permeation of $\mathrm{CNZ}$ by reducing drug-tissue binding. OA and $\mathrm{Gl}$ enhanced percutaneous absorption of CNZ by decreasing phase transition temperatures of skin lipids and displaying the occulusion effect on the skin, respectively. ${ }^{19,29}$ All formulations were affirmed to reach the steady-state flux (Js) at the $1^{\text {st }}$ hour, except for the base formulation $G$ ( $3^{\text {rd }}$ hour).

CNZ percent in the stratum corneum and the receptor phase that was determined for each formulation at the $6^{\text {th }}$ hour are presented in Figure 4. It was found that amount of CNZ accumulated in the stratum corneum was significantly higher than determined in the receptor compartment. As can be seen in the figure, G-Tc displayed the highest skin penetration of the drug followed by formulations G-Gl, G-OA, G-PG and, o/w emulsion based and oleaginous cream based formulations, respectively ( $p<0.05$ ). Formulations displayed high drug accumulation in the stratum corneum were expected to exhibit continuous drug permeation of most of the retained drug by steady state flux in time.

The melting point of $\mathrm{CNZ}$ was found as $121.94^{\circ} \mathrm{C}\left(121.16^{\circ} \mathrm{C}\right.$ onset melting temperature and $98.18 \mathrm{~J} / \mathrm{g}$ melting enthalpy) according to its DSC thermogram indicating a sharp melting peak (Figure 5).
A
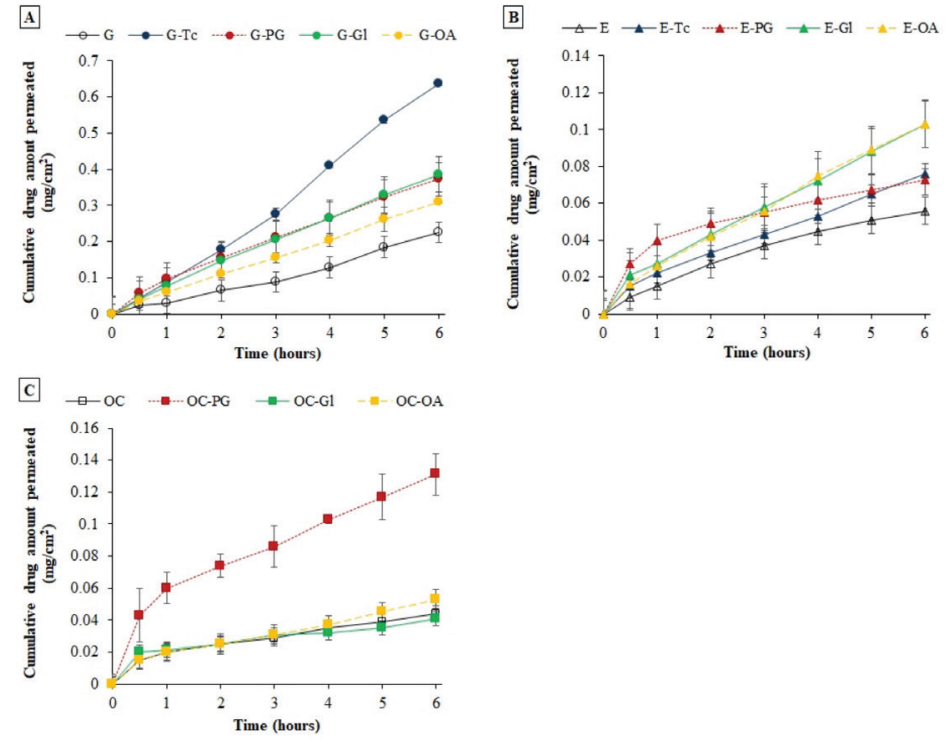

Figure 3. Permeation profiles of CNZ through rat skins. (A) Hydrogel based formulations, $(B)$ o/w emulsion based formulations and (C) oleginous cream based formulations

CNZ: Cinnarizine, G: Hydrogel, E: o/w emulsion, OC: Oleaginous cream, Tc: Transcutol ${ }^{\circledast}$, PG: Propylene glycol, Gl: Glycerole, OA: Oleic acid 
Table 5. Permeation parameters of CNZ through the skin

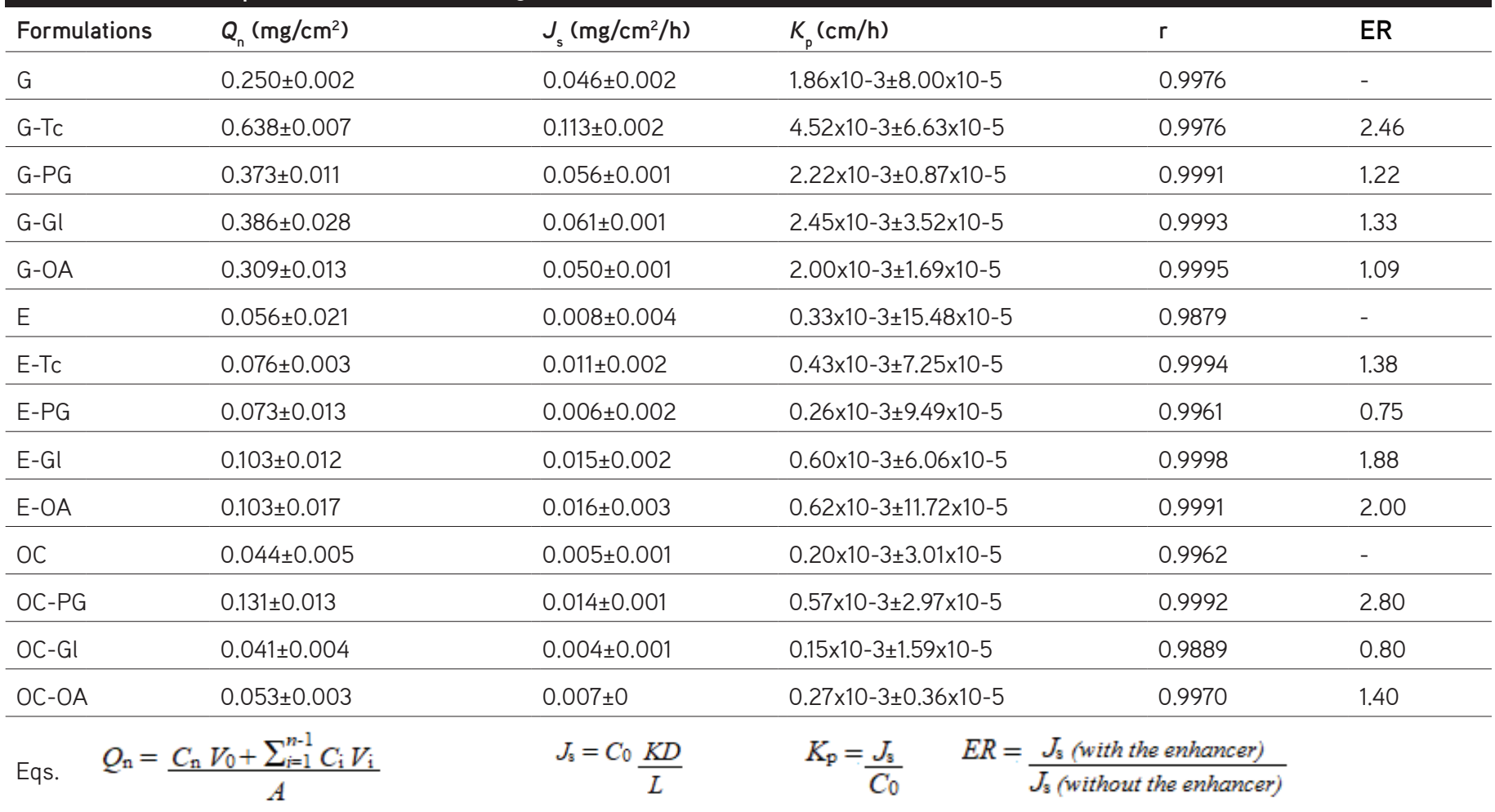

$Q_{n}$ : Cumulative amount of the drug permeated, $C_{n}$ : Drug concentration in the receptor phase at the $n^{\text {th }}$ sampling interval, $A$ : Effective diffusion area (surface of the sample cell), $V_{0}$ and $V_{i}$ : Volumes of the receptor phase in the individual Franz cell and the sample, respectively, $\sum_{i=1}^{n-1} C_{i}$ : Sum of drug concentration determined at sampling intervals 1 through $n-1, J$ : Steady state flux of the drug, $C_{\text {: }}$ : Constant drug concentration in the donor phase, $D$ : Diffusion coefficient, $L:$ Thickness of the membrane, $K$ : partition coefficient of the drug and the vehicle, $K_{\mathrm{p}}$ : Permeability coefficient, $r$ : Correlation coefficient, ER: The enhancement ratio, CNZ: Cinnarizine, G: Hydrogel, E: o/w emulsion, OC: Oleaginous cream, Tc: Transcutol ${ }^{\oplus}$, PG: Propylene glycol, Gl: Glycerole, OA: Oleic acid

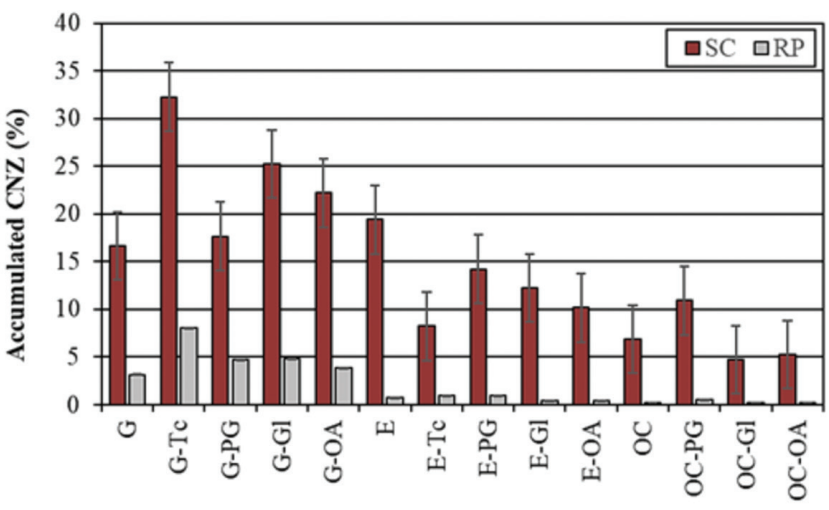

Figure 4. The cumulative amount of CNZ (\%) retained in the stratum corneum (SC) of rat skins and remained in the receptor compartment (RC) after $6 \mathrm{~h}$ of application of the formulations

CNZ: Cinnarizine, G: Hydrogel, E: o/w emulsion, OC: Oleaginous cream, Tc: Transcutol ${ }^{\circledR}$, PG: Propylene glycol, Gl: Glycerole, OA: Oleic acid

The solubility constraint $\left(\sigma_{\mathrm{sc}}\right)$ of CNZ was calculated as 1.88 in the stratum corneum indicating the potential of this compound that forms a reservoir in the stratum corneum. Organic substances with high melting points and enthalpies have lower aqueous solubility in general since solvents cannot pass into the crystalline structure of such molecules to dissolve them. ${ }^{30,31}$ Thus, an indirect relationship exists between the melting point and the solubility of a drug. ${ }^{32}$ In other words, a decrease in the

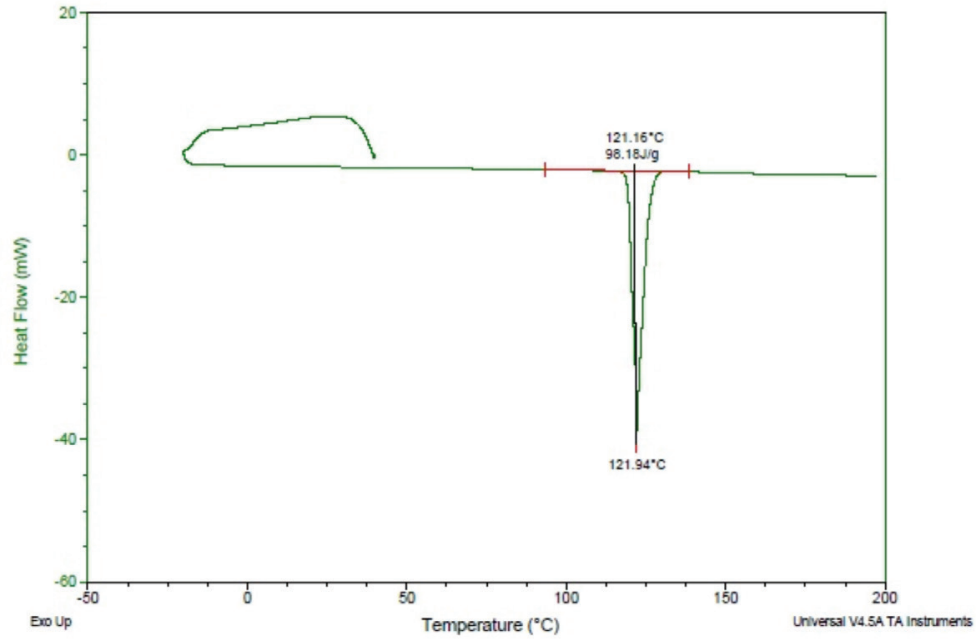

Figure 5. DSC thermogram of the drug (CNZ)

CNZ: Cinnarizine, DSC: Differential scanning calorimetry

melting point of a drug would lead to an increase in its solubility in the stratum corneum and consequently its penetration and then permeation through the skin.

\section{CONCLUSION}

Formulations that were studied in this research introduce various advantages over many transdermal drug delivery 
systems. They are suitable for large-scale production and cost-effective dosage forms produced with excipients used in pharmaceuticals and cosmetics for years. Ex vivo study conducted on rats gave information about the influence of the polarity of vehicles and penetration enhancer on skin penetration of CNZ. It was concluded that skin penetration increased as the lipophilicity of the vehicle decreased. The hydrogel formulation without a penetration enhancer provided about five times higher drug permeation compared to an o/w emulsion and oleaginous cream. Furthermore, when Transcutol ${ }^{\circledast}$ was introduced to the HPMC hydrogel, it displayed the highest penetration enhancer activity. As a result, the HPMC hydrogel containing Tc can be suggested as a suitable carrier for CNZ intended to be used topically for relief of various conditions.

\section{ACKNOWLEDGEMENTS}

This study was supported by the Research Fund of Istanbul University (project number: 40188) and TUBITAK (The Scientific and Technological Research Council of Turkey) (grant number: TEYDEB 1649B031305845).

Conflict of interest: No conflict of interest was declared by the authors. The authors are solely responsible for the content and writing of this paper.

\section{REFERENCES}

1. Sweetman SC. Martindale: The complete drug reference $\left(36^{\text {th }}\right.$ ed). New York; Pharmaceutical Press; 2009.

2. Haress NG. Cinnarizine: Comprehensive Profile. Profiles Drug Subst Excip Relat Methodol. 2015;40:1-41.

3. Lopes LB, Garcia MT, Bentley MV. Chemical penetration enhancers. Ther Deliv. 2015;6:1053-1061.

4. Trommer $\mathrm{H}$, Neubert RH. Overcoming the Stratum corneum: the modulation of skin penetration. A review. Skin Pharmacol Physiol. 2006;19:106-121.

5. Remon JP. Absorption Enhancers. In: Swarbrick J, ed. Encyclopedia of pharmaceutical technology, Vol. 1 ( $3^{\text {rd }}$ ed). New York; Informa Healthcare. 2007:13-18

6. Patwardhan S, Patil M, Sockalingam A. Development and evaluation of naproxen sodium gel using piper cubeba for enhanced transdermal drug delivery and therapeutic facilitation. Recent Pat Drug Deliv Formul. 2017;11:28-35.

7. Dahlizar S, Futaki M, Okada A, Yatomi C, Todo H, Sugibayashi K. Combined Use of $\mathrm{N}$-palmitoyl-glycine-histidine gel and several penetration enhancers on the skin permeation and concentration of metronidazole. Pharmaceutics. 2018;10:163.

8. Koyama Y, Bando H, Yamashita F, Takakura Y, Sezaki H, Hashida M. Comparative analysis of percutaneous absorption enhancement by d-limonene and oleic acid based on a skin diffusion model. Pharm Res. 1994:11:377-383.

9. Prasanthi D, Lakshmi PK. Effect of chemical enhancers in transdermal permeation of alfuzosin hydrochloride. ISRN Pharm. 2012;2012:965280.
10. Vijaya C, Bingi M, Vigneshwaran LV. Transdermal delivery of venlafaxine hydrochloride: the effects of enhancers on permeation across pig ear skin. Indian J Pharm Sci. 2011;73:456-459.

11. Liu X, Quan P, Li S, Liu C, Zhao Y, Zhao Y, Fang L. Time dependence of the enhancement effect of chemical enhancers: Molecular mechanisms of enhancing kinetics. J Control Release. 2017;248:33-44.

12. Moghimipour E, Salimi A, Zadeh BSM. Effect of the various solvents on the in vitro permeability of vitamin B12 through excised rat skin. Trop $J$ Pharm Res. 2013;12:671-677.

13. Maurya A, Murthy SN. Pretreatment with skin permeability enhancers: importance of duration and composition on the delivery of diclofenac sodium. J Pharm Sci. 2014;103:1497-1503.

14. Monti D, Egiziano E, Burgalassi S, Chetoni P, Chiappe C, Sanzone A, Tampucci S. Ionic liquids as potential enhancers for transdermal drug delivery. Int J Pharm. 2017;516:45-51.

15. ICH Harmonised Tripartite Guideline: Validation of Analytical Procedures: Text and Methodology Q2 (R1). Harmonization Co, Editor. 2005.

16. Üner M, Karaman EF. Preliminary studies on solid lipid microparticles of loratadine for the treatment of allergic reactions via the nasal route. Trop J Pharm Res. 2013;12:287-293.

17. Higuchi T. Mechanism of sustained action medication. Theoretical analysis of rate of release of solid drugs dispersed in solid matrices. $J$ Pharm Sci. 1963;52:1145-1149.

18. Korsmeyer RW, Gurny R, Doelker E, Buri P, Peppas NA. Mechanisms of solute release from porous hydrophilic polymers. Int J Pharm. 1983;15:25-35

19. Williams AC, Barry BW. Penetration enhancers. Adv Drug Deliv Rev. 2004;56:603-618.

20. Haq A, Michniak-Kohn B. Effects of solvents and penetration enhancers on transdermal delivery of thymoquinone: permeability and skin deposition study. Drug Deliv. 2018;25:1943-1949.

21. Sloan KB, Koch SA, Siver KG, Flowers FP. Use of solubility parameters of drug and vehicle to predict flux through skin. J Invest Dermatol. 1986;87:244-252.

22. Houston DM, Bugert J, Denyer SP, Heard CM. Anti-inflammatory activity of Punica granatum L. (Pomegranate) rind extracts applied topically to ex vivo skin. Eur J Pharm Biopharm. 2017;112:30-37.

23. Hadgraft J, Brain KR. Xenobiotic experimentation: predicting percutaneous penetration. In: Marks R, Plewig G, eds. The environmental threat to the skin. London; CRC Press, Taylor \& Francis Group; 1992:179184.

24. European Medicine Agency, Draft Guideline on quality and equivalence of topical products (EMA/CHMP/QWP/708282/2018).

25. Surber C, Smith E. The vehicle: The pharmaceutical carrier of dermatological agents. In: Gabard B, Surber C, Elsner P, Surber C, Treffel $P$, editors. Dermatopharmacology of topical preparations. A product development-oriented approach. Berlin; Springer-Verlag; 2000:5.

26. Salerno C, Carlucci AM, Bregni C. Study of in vitro drug release and percutaneous absorption of fluconazole from topical dosage forms. AAPS PharmSciTech. 2010;11:986-993.

27. Watkinson RM, Guy RH, Oliveira G, Hadgraft J, Lane ME. Optimisation of cosolvent concentration for topical drug delivery III--influence of 
lipophilic vehicles on ibuprofen permeation. Skin Pharmacol Physiol. 2011;24:22-26.

28. Harrison JE, Watkinson AC, Green DM, Hadgraft J, Brain K. The relative effect of Azone and Transcutol on permeant diffusivity and solubility in human Stratum corneum. Pharm Res. 1996;13:542-546.

29. Pathan IB, Setty CM. Chemical penetration enhancers for transdermal drug delivery systems. Trop J Pharm Res. 2009;8:173-179.

30. N'Da DD. Prodrug strategies for enhancing the percutaneous absorption of drugs. Molecules. 2014;19:20780-20807.
31. Lipinski CA, Lombardo F, Dominy BW, Feeney PJ. Experimental and computational approaches to estimate solubility and permeability in drug discovery and development settings. Adv Drug Deliv Rev. 2001;46:3-26.

32. Stott PW, Williams AC, Barry BW. Transdermal delivery from eutectic systems: enhanced permeation of a model drug, ibuprofen. J Control Release. 1998;50:297-308. 